
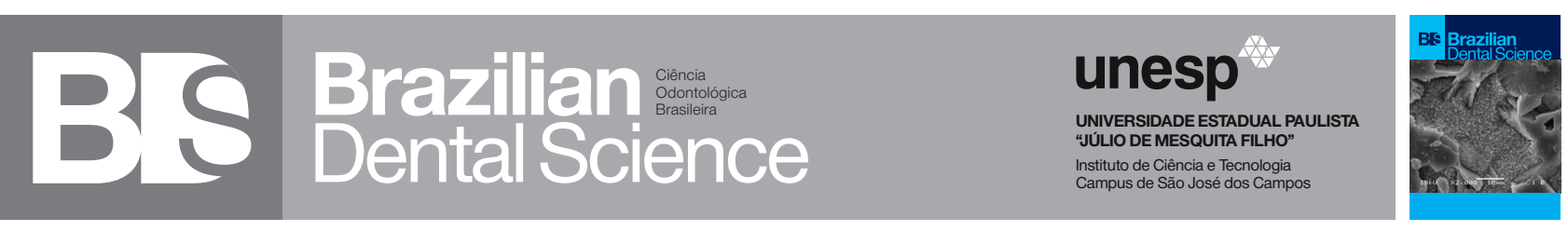

\title{
Retentiveness comparison of individual clasps made from polyamide, acetate resin and cobalt-chrome for removable partial dentures
}

Comparação da retenção de grampos individuais de poliamida, resina de acetato e cromo-cobalto para próteses parciais removíveis

Juan Cruz MUTTO ${ }^{1}$, Tabata Prado SATO ${ }^{1}$, João Mauricio Ferraz da SILVA ${ }^{1}$, Alexandre Luiz Souto BORGES ${ }^{1}$, Eduardo Shigueyuki UEMURA $^{1}$

1 - São Paulo State University (Unesp) - Institute of Science and Technology - São José dos Campos - Department of Dental Materials and Prosthodontics - SP - Brazil.

\begin{abstract}
Objective: This study aimed to evaluate and compare the retention force of individual clasps made from polyamide, acetate resin and cobalt-chrome for removable partial dentures. Material and methods: Three groups of clasps were fabricated: $\mathrm{Cr}-\mathrm{Co}-10$ conventional chrome-cobalt metal clasps; Ac - 10 clasps with reciprocal arms and occlusal rests in chrome-cobalt and retentive arms in acetate resin; and Poly - 10 clasps with reciprocal arms and occlusal rests in chrome-cobalt and retentive arms in polyamide resin. Through the tensile test, in a universal testing machine, the initial retention force of the specimens was obtained and then clasps were cycled 7200 times, immersed in artificial saliva (60 months of simulated clinical use). After cycling, tensile test was performed. Results: All groups presented a retention decrease after the cycling. Ac presented a large reduction in retentive force $(61.43 \%)$, followed by Cr-Co (26.5\%) and Poly (12.09\%). Conclusions: Aesthetic clasps of polyamide can be used in clinical cases where the anterior supporting teeth will not be essential for good retention of the removable partial denture because this clasp showed to be more resistant than the acetate resin.
\end{abstract}

\section{KEYWORDS}

Removable partial denture; Esthetic clasp; Metal clasp.

\section{RESUMO}

Objetivo: Este estudo teve como objetivo avaliar e comparar a força de retenção de grampos individuais feitos de poliamida, resina de acetato e cromo-cobalto para próteses parciais removíveis. Material e Métodos: Três grupos de grampos foram fabricados: $\mathrm{Cr}$-Co - 10 grampos metálicos convencionais de cromo-cobalto; Ac - 10 grampos com apoios e braço de oposição em cromocobalto e braços de retenção em resina de acetato; e Poly - 10 grampos com apoios e braço de oposição em cromo-cobalto e braço de retenção em resina de poliamida. Por meio do teste de tração, em uma máquina de ensaio universal, a força de retenção inicial dos espécimes foi obtida e então, os grampos foram ciclados 7200 vezes, imersos em saliva artificial (60 meses de uso clínico simulado). Após a ciclagem, o teste de tração foi realizado. Resultados: Todos os grupos apresentaram diminuição da retenção após a ciclagem. Ac apresentou uma grande redução na força retentiva (61,43\%), seguida por Cr-Co (26,5\%) e Poly (12,09\%). Conclusões: Grampos estéticos de poliamida podem ser usados em casos clínicos em que os dentes de suporte anteriores não serão essenciais para uma boa retenção da prótese parcial removível, pois esse grampo mostrouse mais resistente que os de resina de acetato.

\section{PALAVRAS-CHAVE}

Prótese Parcial Removível; Grampo estético; Grampo Metálico. 


\section{INTRODUCTION}

$\mathrm{R}$ emovable partial denture (RPD) is used for functional restoration of the stomatognathic system, but functional and aesthetic restoration is a continuous challenge for prosthetic rehabilitation. [1]

A initial quality planning, retention and stability are good predictors of RPD clinical acceptance. [2] The clinician are responsible for RPD design and the aesthetic condition have great importance to the patient, besides that visible retentive structures causes RPD rejection. [3, 4]

Ideally, RPD should have adequate biomechanical properties, satisfactory retention, stability and stress absorption that depends on professional training with skills and the experience of the laboratory technician. [5]

Besides that, one of the most critical requirements is the balance between forces distribution, flexibility, retention and reciprocity. [6] But often RPD does not completely restore aesthetics because the clasps are made by metallic alloys such as cobalt-chromium [Co-Cr], gold and titanium alloy. [7] As an option, already studied, materials such as polyamide and acetate resins have been used in RPD. [5]

In this sense, one of the great doubts about the functionality of soft and flexible prostheses is that comfort is a momentary illusion, since several experiments have already been carried out with soft materials. [8-10] And it can be said that the harder the material presents, the more it favors its properties of support.

One problem with metal alloy is that they can undergo permanent deformation when exposed to repeated forces. This may occur in the retention clip during insertion and removal of the removable partial denture, especially when they are calibrated with excess retention. As for the polyamide resin, there are few studies and knowledge about its deformation regarding its use in the manufacture of aesthetic clasps. [11]

Although intracoronal [precision] and extracoronal [resilient] attachments can be used for aesthetic resolutions, it requires sensitive technique procedures that may increase the chance of laboratory errors. [12] In addition, the attachments are always associated with prosthetic crowns, which makes the procedure more invasive in terms of dental wear, and increases the cost of the treatment. Therefore, the options of working with acetate and polyamide clasps, associated to a conventional metal frame of Removable Partial Denture, can be a good option in terms of aesthetics allied to function, aiming a greater longevity of the prosthesis.

Faced with this the objective of this study is to evaluate and compare the retention force of individual clasps made from polyamide, acetate resin and cobalt-chrome for removable partial denture.

\section{MATERIAL AND METHODS}

\section{Materials}

The materials used for clasp fabrication were Co-Cr alloy (Kota, Ind. e Com., Sao Paulo, $\mathrm{SP}$, acetate resin (Dental D, Biodent, Goodna, Australia] and polyamide resin (Deflex classic SR, Buenos Ares, AR]

\section{Clasps design and fabrication}

A silicone impression (Aquasil, Dentsply, Ind. e Com. Ltda, Petrópolis, RJ, Brazil] was made from a pre-molar tooth and a wax template with a base - perpendicular to the path of insertion - was obtained. And in this wax template, orientation guide and occlusal rest on the distal surface were performed. 
The specimen was sent to the laboratory to obtain a Cr-Co tooth, where different types of clasps were made according to the experimental groups:

Cr-Co: 10 conventional chrome-cobalt metal clasps

Ac: 10 clasps with reciprocal arms and occlusal rests in chrome-cobalt and retentive arms in acetate resin

Poly: 10 clasps with reciprocal arms and occlusal rests in chrome-cobalt and retentive arms in polyamide resin.

\section{Initial retention analysis}

The specimens were submitted to a tensile strength test in universal testing machine (EMIC] to determine the retention of the clasps before the cycling.

\section{Simulated Cycling}

The specimens, immersed in artificial saliva, were cycled by a test apparatus, specially configured for clasps insertion and removal intervals corresponding to $2 \mathrm{~s}$.

Providing a mean number of insertions and removals loss of retention force was measured as the clasps underwent 60 months of simulated clinical use (7200 cycles) of a RPD.

\section{Final retention analysis}

After the cycling, the specimens were again submitted to the tensile strength test to determine the retention of the clasps after the cycling.

\section{RESULTS}

Specimens loss of retention are illustrated and average values of tensile strength, referring to the three types of clasps and the different periods of the test, before and after the cycling, are presented in Table 1.
Table 1 - Average with standard deviation and loss of retention from experimental groups

\begin{tabular}{|cccc|}
\hline & Cr-Co & Ac & Poly \\
\hline Initial (kgf] & $1,713 \pm 0,722$ & $0,869 \pm 0,443$ & $0,852 \pm 0,169$ \\
\hline Final (kgf] & $1,259 \pm 0,578$ & $0,335 \pm 0,193$ & $0,749 \pm 0,211$ \\
\hline $\begin{array}{c}\text { Loss of retention } \\
\text { (\%) }\end{array}$ & 26,5 & 61,43 & 12,09 \\
\hline
\end{tabular}

All groups presented a retention decrease after the cycling. Ac presented a large reduction in retentive force (61.43\%], followed by Cr-Co (26.5\%] and Poly (12.09\%]

In the context of the loss retention as a function of the clasp material, it was used the ANOVA One-way for analysis and the results are presented in Table 2.

Table 2 - Results from loss retention as a function of the clasp material analysis

\begin{tabular}{|c|c|c|c|c|c|}
\hline & SS & Degr. of & MS & $\mathbf{F}$ & $\mathbf{P}$ \\
\hline Intercept & 4,217250 & 1 & 4,217250 & 39,88017 & 0,000001 \\
\hline Material & 0,885312 & 2 & 0,442656 & 4,18595 & 0,026093 \\
\hline Error & 2,855197 & 27 & 0,105748 & & \\
\hline
\end{tabular}

There was a statistically significant difference $(p>0.05)$ for the intercept between Material and loss of retention.

In order to evaluate the interaction effect of the material and the performance of the cycling in the retention of the clasps, the ANOVA two-way test was applied (Table 3).

Table 3 - Results of interaction effect of the material and the performance of the cycling in the retention of the clasps

\begin{tabular}{|cccccc|} 
& SS & $\begin{array}{c}\text { Degrees } \\
\text { Of } \\
\text { Freedom }\end{array}$ & MS & F & P \\
\hline Intercept & 55,66333 & 1 & 55,66333 & 287,2569 & 0,000000 \\
\hline Material & 8,61256 & 2 & 4,30628 & 22,2230 & 0,000000 \\
\hline Cycling & 1,98417 & 1 & 1,98417 & 10,2395 & 0,002303 \\
\hline Material & 0,52683 & 2 & 0,26341 & 1,3594 & 0,265467 \\
\hline $\begin{array}{c}\text { Material* } \\
\text { Cycling }\end{array}$ & 10,46387 & 54 & 0,19378 & & \\
\hline
\end{tabular}


Thus, it was possible to verify that between the materials and in relation to the cycles there was a statistical difference ( $p<0.05$ ), while the interaction material/cycling was not statistically significant $(p>0.05)$.

It can be verified statistical difference in Tukey test (5\%), applied for the relation between initials and finals retentions of the different clasps types, as indicated in Table 4.

Table 4 - Initial and final retention values as a function of the experimental groups

\begin{tabular}{|c|c|c|c|c|c|}
\hline Material & Ciclos & Resistencia & $\mathbf{1}$ & $\mathbf{2}$ & $\mathbf{3}$ \\
\hline Ac & final & 0,335400 & A & & \\
\hline Poly & final & 0,749100 & A & B & \\
\hline Poly & inicial & 0,851800 & A & B & \\
\hline Ac & inicial & 0,869500 & A & B & \\
\hline CoCr & final & 1,259500 & & B & C \\
\hline CoCr & inicial & 1,713800 & & & C \\
\hline
\end{tabular}

\section{DISCUSSION}

In terms of insertion and removal of the RPDs, the effect of the reciprocal arm is extremely necessary, while the retention arm flexes as it passes over the dental equatorial line. [13]

Therefore, the reciprocal arm of the clasps must be designed to produce reciprocity and also stability to the prosthesis when under horizontal forces. [14,15]

Previous studies already have been performed with acetate resin clasps, [5] under full manufacture in acetate, [16] or with metal frame [reciprocal arms and occlusal rests in chrome-cobalt] and only the thermoplastic resin retention arm, [17] in this configuration, a more favorable stress distribution was found than in prostheses made entirely of thermoplastic resin.

The results in our study showed that acetate clasps, after cycling, presented a significant loss of retention (0.869 to 0.335 $\mathrm{kgf}$ ), representing $61.43 \%$. The polyamide resin clasp showed lower loss of retention (0.852 to $0.749 \mathrm{kgf}$ ) compared to other specimens (12.6\%) The metal clasps also presented loss of retention (1.71 to $1.25 \mathrm{kgf}$ ) representing $26.5 \%$ of the initial retention, but they still maintained a acceptable retention value.

Both acetate and polyamide clasp presented values of resistance to removal, before and after the cycling, below the values of the metal clasp. Statistical difference was observed in the acetate group in relation to the other two groups, with loss of $61.43 \%$ of the retention

Despite its significant aesthetic, acetate or polyamide clasps during insertion and removal, promotes flexure of retention arm, in accordance with the results of the present study. [16] This is because, biomechanically, the acetate reciprocal arm will not perform the reciprocity function, such as it will not work on the latero-lateral stability of the prosthesis and for acetate support, there is a risk of fracture and the intrusion of the RPD if there is not adequate thickness. [18]

In our study, using metal support and reciprocal arm, the acetate retention arm suffered more during insertion and removal, causing a greater loss of retention. However, the polyamide resin clasp showed a different result, it was observed that it presented lower retention loss when compared to the acetate clasp and Co-Cr, even though the metal clasp showed a higher removal resistance in the insertion / removal trajectory.

Table 4 shows that in the polyamide group there was no significant difference between the initial and final retention values [after cycling], but there was a statistical difference between the initial Co-Cr clasp and the acetate clasp after cycling. 
Thus, although the Co-Cr clasp is more retentive, the aesthetic clasps may be an outlet for use in regions where aesthetics are important and retention is necessary in removable partial denture.

\section{CONCLUSIONS}

Given the conditions researched and the limitations of this study, we can conclude that:

- The Co-Cr clasp showed the highest retention values before and after the cycles;

- The polyamide clasp had the lowest loss of retention after the cycles, followed by the Co-Cr clasps, and the acetate clasp had the highest loss of retention.

\section{REFERENCES}

1. Nair SJ, Aparna IN, Dhanasekar B,Prabhu N. Prosthetic rehabilitation of hemimandibulectomy defect with removable partial denture prosthesis using an attachment-retained guiding flange. Contemp Clin Dent. 2018;9(1):120-2 .

2. Santos MB, Carvalho RM, Guimarães TS, Santos JF, Marchini L Longitudinal study of removable partial dentures and hygiene habits. Braz Dent Sci. 2010;10(3)

3. Khan S, Geerts G. Aesthetic clasp design for removable partial dentures: a literature review. SADJ.2005 Jun;60(5):190-4.

4. Owen CP.Fundamentals of Removable Partial Dentures. Landsdowne, Cidade do cabo (South Africa): University of Cape Town Press;2000.
5. YamamotoETC, Sato TP, da Silva JMF, Borges ALS, Uemura ES. Retentive force comparison between esthetic and metal clasps for removable partial denture. Brazilian Dental Science. 2017;20(3):87-92

6. McGivney G,Castleberry,DJ. McCracken's removable partial prosthodontics. 8 th StLouis:CV Mosby; 1989.78-124p.

7. Beaumont Jr AJ. An overview of esthetics with removable partial dentures. Quintessence int. 2002;33(10)

8. Sato $\mathrm{Y}, \mathrm{Abe} \mathrm{Y}, \mathrm{Okane} \mathrm{H}$, Tsuga $\mathrm{K}$. Finite element analysis of stress relaxation in soft denture liner. J oral rehab. 2000;27(8):660-3.

9. Qudah S, Harrison A, HuggettR. Soft Lining Materials in Prosthetic Dentistry; A Review. Int JProsthod. 1990;3(5)

10. Araújo CU, Basting RT. In situ evaluation of surface roughness and micromorphology of temporary soft denture liner materials at different time intervals. Gerodontology.2018 Mar;35(1):38-44. doi:10.111//ger.12314.

11. Ucar Y,Akova T, Aysan I. Mechanical properties of polyamide versus different PMMA denture base materials. J Prosthodont. 2012 Apr;21(3):173-6. doi: 10.1111/j.1532-849X.2011.00804.X.

12. Hansen CA, Iverson GW. An esthetic removable partial denture retainer for the maxillary canine.J Prosthetic Dent. 1986;56(2):199-203.

13. Zanetti AL, LaganáDC. Planejamento: prótese parcial removivel. São Paulo: Sarvier; 1996

14. Rudd RW, Bange AA, Rudd KD, Montalvo R. Preparing teeth to receivea removable partial denture. J Prosthet Dent. 1999 Nov;82(5):536-49.

15. Krol AJ. Clasp design for extension-base removable partial dentures. J Prosthet Dent. 1973 Apr;29(4):408-15. doi: 10.1016/s0022-3913(73)80018-6

16. Arda T,Arikan A. An in vitro comparison of retentive force and deformation of acetal resin and cobalt-chromium clasps. J Prosthet Dent. 2005 Sep;94(3):267-74.

17. Jiao T,Chang T,Caputo A. Load transfer characteristics of unilateral distal extension removable partial dentures with polyacetal resin supporting components. AustDent J.2009 Mar;54(1):31-7. doi: 10.1111//.18347819.2008.01085.x.

18. Kaplan P.Flexible removable partial dentures: design and clasp concepts. Dent Today. 2008;27(12):120,2.

Tabata Prado Sato

(Corresponding address)

Av. Dr. Eng.Francisco Jose Longo, 777, Jd. Sao Dimas $\quad$ Date submitted: 2019 Jun 13
Sao Jose dos Campos, Brazil

Accept submission: 2019 Aug 14 